Fournal of Medical Genetics (1972). 9, 86.

\title{
Development of Humoral and Cellular Immunity in Man
}

\author{
M. ADINOLFI and M. H. LESSOF
}

From the Paediatric Research Unit and Department of Medicine, Guy's Hospital Medical School, London SE1

Recent studies have radically changed our views of the development of acquired immunity during gestation and perinatal life. It is now apparent that there are considerable differences in the way the immune response matures in different species (Sterzl and Silverstein, 1967; Adinolfi and Wood, 1969; Solomon, 1971). In mice and rats immune reactions are relatively immature even in the newborn. In the lamb, on the other hand, some degree of immunological competence is achieved about two-thirds of the way through fetal life (Silverstein and Prendergast, 1970). In man, too, both humoral and cellular immunity are well developed before birth.

\section{The Thymus}

The first lymphoid organ to develop in the mammalian fetus is the thymus; there is evidence that in mammals and birds thymocytes differentiate from stem cells that have migrated into the epithelial rudiment from the yolk sac (Moore and Owen, 1967). In some mammals neonatal thymectomy prevents the development of cellular immunity and depresses both homograft rejection and delayed hypersensitivity. Thymectomy also impairs the humoral antibody response to certain antigens (Hess, 1968).

In the human fetus the thymus is an active lymphoid organ after 6 weeks of gestation. Lymphopoiesis in the thymus is intense and is independent of antigenic stimulation. However, recent observations have shown that at 20 weeks, the thymus of the human fetus may contain thymocytes which bind flagellins well before the fetal spleen or peripheral lymphocytes show the same degree of flagellin binding (Dwyer and MacKay, 1970). Since

Received 14 September 1971. flagellin tends to provoke a humoral antibody response, it is possible that in man the fetal thymus may itself produce humoral antibody or else that it influences the development of a diversity of antibody patterns (Burnet, 1970; Dwyer and MacKay, 1970).

\section{Antibody Production in the Fetus}

By using cultures of fetal tissues in vitro, van Furth, Schuit, and Hijmans (1965) showed that the human fetus is capable of producing immunoglobulins after the 20th week of gestation; immunofluorescent staining of fetal spleen cells confirmed the synthesis of both IgG and IgM. Peripheral fetal blood was also found to contain a few medium sized lymphocytes giving the staining reactions of these proteins.

However, plasma cells in the normal fetus remain scanty, even during the last month of gestation. This may be due to an environment which is protected from antigenic stimulation, since in congenital infections plasma cells are often present in fetal tissues. The presence of plasma cells in the liver of newborns with congenital syphilis was observed for the first time by Porcile (1904). Silverstein and Lukes (1962) have shown that both congenital syphilis and toxoplasmosis may be associated with infiltration of plasma cells into various fetal tissues. Very young fetuses may, however, have a positive stain for the treponeme in the complete absence of an inflammatory response. Early infection may not cause sufficient damage to result in the death or expulsion of the fetus, though it can still interfere with parenchymal cells in the liver. The immunological immaturity of the fetus appears to allow the infective agent to persist in the tissues, but it does not necessarily follow that the fetus becomes tolerant to the invading organism. 
Following intrauterine infections, specific antibodies and high levels of IgM have been detected in cord sera. In congenital rubella abnormal levels of IgM were observed in serum from newborns by Alford (1965) and Alford et al (1967), while occasionally the synthesis of IgG has been found to be depressed (Soothill, Hayes, and Dudgeon, 1966). Elevated levels of IgM globulins have also been detected in neonates with cytomegalic inclusion diseases (McCracken and Shinefield, 1965) and in infants with congenital infection with Toxoplasma gondii (Remington and Miller, 1966).

Antibodies associated with IgM molecules, which are not transferred through the human placenta, have been demonstrated in normal newborns (Table). These include anti-I cold agglutinins (Adinolfi, 1965), IgM antibodies which cause reversible agglutination of trypsinized red cells (Mellbye, 1966), and occasionally anti-A and anti-B agglutinins (Adinolfi and Wood, 1969).

\section{TABLE}

DATA SUPPORTING THE ANTENATAL SYNTHESIS OF IMMUNOGLOBULINS*

1. In vitro synthesis of $\gamma \mathrm{M}$ and $\gamma \mathrm{G}$ globulins using fetal spleen and lymph nodes

2. Presence in normal cord sera of

a. IgM antibodies not derived from the maternal circulation

b. IgG variants which are absent in the mother and are synthesized by the fetus under the control of paternal genes

3. Presence of antibodies against viruses and bacteria in infants with congenital infections

4. Cellular immunity in fetuses and premature newborns

* References quoted in Adinolfi and Wood (1969).

Evidence for the synthesis of IgG during life in utero has been confirmed by the detection, in cord sera, of IgG molecules with genetic markers absent in the maternal serum (Vierucci, Varone, and Ingiulla, 1964; Mårtensson and Fudenberg, 1965; Mårtensson, 1966). By means of highly specific antisera against allotypic IgG molecules, Gm specificities which are not present in maternal serum have been detected in newborn samples. The demonstration that through normal pregnancy some mothers produce anti-Gm antibodies has shown that the normal human fetus is capable of producing IgG molecules with antigenetic determinants inherited from the father; these molecules cross the human placenta and induce an immune response in the mother.

In a recent paper Wang et al (1970) have suggested that a specific fetal IgG is synthesized in man.

In contrast to the good evidence for the production of IgG and IgM on fetal life, IgA has been shown to be present in very low concentrations in the normal neonate (Heremans, 1960; West, Hong, and
Holland, 1962; Adinolfi et al, 1966; Faulkner and Borella, 1970). However, high levels of IgA have been detected in infants with congenital infections (Stiehm and Fudenberg, 1966). IgD has not been detected in cord serum and its synthesis begins some time after birth (Rowe, Crabbé, and Turner, 1968). On the other hand, IgE has been found in cord serum without obvious correlation between the level of this protein in maternal and cord samples. This suggests that this class of immunoglobulins is produced in utero.

\section{Antibody Production in the Newborn}

The results of the studies on the ontogeny of acquired immunity have an additional relevance to the use of immunization procedures in neonatal life. The literature of the antibody response in perinatal life has been extensively and critically analysed by Smith (1968) and Davies (1971). Even premature infants appear to produce antibodies to Salmonella and typhoid-paratyphoid antigens (Smith, 1960; Fink et al, 1962). Koprowski et al (1956) have also found that premature babies respond to live polio vaccine. However, the response of the newborn cannot always be predicted for a variety of reasons.

The control of the synthesis of specific antibodies during fetal and perinatal life has been studied by Perkins, Yetts, and Gaisford (1958 and 1959) and Butler et al (1962), who observed that the immune response of infants injected with poliomyelitis vaccine is often depressed in the presence of maternal antibodies. A comparable effect was noticed by Smith and Eitzman (1964) in infants intentionally stimulated with Salmonella antigens.

Levi et al (1969) came to a similar conclusion after comparing the titre of maternal antibodies to pertussis, diphtheria, and tetanus antigens with the immune response to these antigens during perinatal life. They suggest that antibody synthesis is depressed in babies immunized shortly after birth in the presence of high levels of maternal antibodies. On the other hand, the synthesis of antibodies may be increased in newborn infants when the level of maternal antibodies of the same specificity is low.

\section{Cellular Immunity in the Fetus}

Cellular immunity seems also to develop at an early stage of gestation, as judged by tests in vitro using transplantation antigens. Histocompatibility antigens of the major systems have been detected in human fetuses at an early stage of gestation (Ceppellini et al, 1971; Crome, Moffat, and Adinolfi, 1971).

More important is the evidence that lymphocytes from fetuses more than 15 weeks' old are already 
competent to react in vitro against allogeneic stimuli. Figure 1 shows the reaction of lymphocytes, obtained from two human fetuses 15 and 16 weeks old;

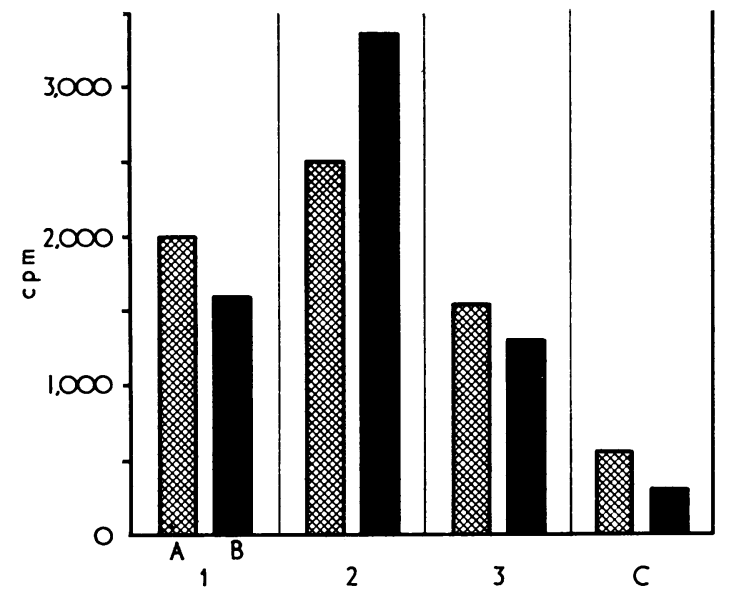

FIG. 1. Reactivity of lymphocytes from two human fetuses $(A=15$ weeks old; $B=16$ weeks old) to HL-A skin extracts prepared from two unrelated adult subjects ( 1 and 2 ) and a 20-week-old fetus (3). The reactivity was measured by the incorporation of tritiated thymidine for 5 hours, after incubation of the cells for $\mathbf{7 2}$ hours. The reactivity of the fetal lymphocytes in the absence of HL-A extract is shown in C.

these cells were cultured in the presence of HL-A antigens extracted from the skin of adult individuals (Crome et al, 1971). The incorporation of ${ }^{3} \mathrm{H}$-thymidine was used as an index of the reactivity of the fetal cells (Adinolfi et al, 1967); there was evidence of a reaction to HL-A extracts taken from adult subjects and also to an extract prepared from a 20-week-old fetus. Ceppellini et al (1971) have also investigated the transplantation reaction of lymphocytes, spleen and thymus cells from human fetuses using a mixed leucocyte culture test. Reactivity to allogenic stimuli was observed in cells obtained from fetuses that were more than 16 weeks old. This evidence that transplantation immunity in man develops at an early stage of gestation is in agreement with the early development of cellular immunity in fetal lambs (Silverstein and Prendergast, 1970).

Transplantation of allogeneic haemopoietic tissue into severely affected homozygote anaemic mice has been successfully achieved (Seller, 1970); similar tissue grafts in infants with inherited haemopoietic disorders will be more difficult to achieve because of the early maturation of cellular immunity during gestation in man.

\section{Complement and Lysozyme}

The immunological competence of the fetus and the newborn depends on many things besides the ability to produce a humoral and cellular response.

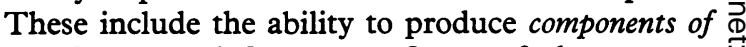
complement and lysozyme. Some of the compo-

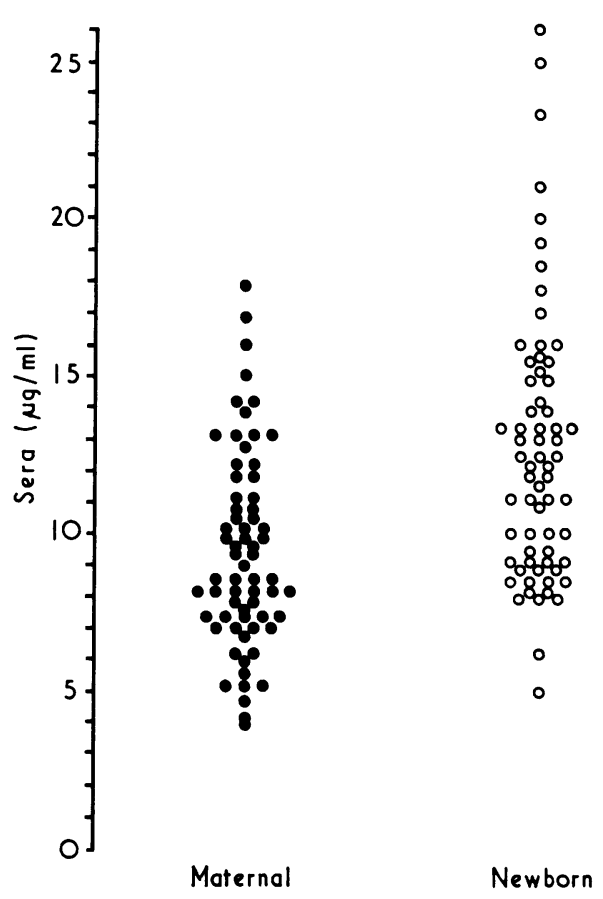

Fig. 2. Levels of lysozyme in 66 pairs of sera. (From Glynn et al, 1970.)

nents of complement $\left(\mathrm{C}_{3}\right.$ and $\left.\mathrm{C}_{4}\right)$ have been shown to be synthesized at the beginning of the second trimester of gestation; all components of complement are present in fetuses that are 18 weeks old (Adinolfi, Gardner, and Wood, 1968; Adinolfi, 1970).

Lysozyme is also present in fetuses more than 12 weeks old and in all newborns; the enzyme was detected in serum from 3 out of 9 fetuses between 9 and 12 weeks old and in all fetuses more than 24 weeks old. The levels of lysozyme in fetuses about 18 weeks old were similar to those observed in normal adults (Glynn, Martin, and Adinolfi, 1970). When the amount of enzyme was compared in maternal and cord sera, it was found that the mean level was higher in the newborn samples $(\overline{\mathbf{x}}=$ $12.59 \mu \mathrm{g} / \mathrm{ml} ; \mathrm{SE}=0.53$ ) than in the corresponding maternal sera $(\bar{x}=9.65 \mu \mathrm{g} / \mathrm{ml} ; \mathrm{SE}=0.37)$. No correlation was observed between the levels of the enzyme in maternal and cord samples; in several newborns the amount of the enzyme was from 3 to 5 
times higher than that observed in the maternal serum (Adinolfi, Martin, and Glynn, 1971).

In mice, the level of lysozyme in newborn liver has been found to be ten times higher than that observed in maternal liver; the amount of the enzyme (expressed in $\mu \mathrm{g} / \mathrm{ml}$ of tissue) decreases during the first 2 weeks of life and at 4 weeks is similar to that observed in normal adults (Adinolfi et al, 1971).

\section{Fetal-maternal Immunological Reactions}

In view of the early maturation of acquired immunity in the human fetus, it is not surprising that occasionally fetal immunological reactions against maternal antigens have been observed. Intrauterine iso-immunization caused by maternal IgA crossing the placenta was noticed in a newborn girl by Vyas, Levin, and Fudenberg (1970). The serum of this infant was found to contain anti-IgA reacting against antigenic determinants expressed in the maternal IgA molecules; the anti-IgA antibodies were not inhibited by IgA present in the father's serum.

In recent years immunological reactions to maternal $\mathrm{Gm}$ antigens of IgG molecules have been described; maternal IgG globulins start to cross the placenta at about the third month of gestation (Mollison, 1951) and it might be expected that the infant would be tolerant to the maternal allotypic IgG molecules. However, the opposite happens; most children produce anti-Gm directed against maternal IgG during the first years of life (Steinberg and Wilson, 1963; Speiser, 1963; Speiser, 1966). This is another example of the fact that foreign antigens may be present from an early stage of development without necessarily inducing a lasting immunological tolerance.

The maturation of cellular immunity at an early stage of gestation is probably responsible for the protection of the fetus against transplacental passage of bacteria. Brody, Oski, and Wallach (1968) observed a mitogenic response in vitro to $E$. coli by lymphocytes from neonates born to mothers who had documented infections of the urinary tract.

The maturation of fetal cellular immunity may have some relevance to fertility, although the observations so far published are not entirely explicable by current concepts. In a study of a Swedish population Seppälä (1971) observed that matings between group $A$ mother and group $O$ father (pseudocompatible mating) produced more pregnancies and more children than did group $\mathrm{A} \times$ group A matings (compatible); in neither case does the conceptus contain $\mathrm{ABO}$ antigens incompatible with the mother, although in the first case the fetus might in theory be capable of an immunological reaction against the mother.

Recently Bagshawe et al (1971) have observed that the risk of choriocarcinoma developing after any form of pregnancy is critically related to the ABO groups of the woman and her husband. Group A women married to group $\mathrm{O}$ husbands have a higher risk of developing choriocarcinoma than group $\mathrm{A}$ women married to group $A$ husbands; group $A B$ patients tend to have rapidly progressive tumours which do not respond well to chemotherapy.

It is of interest that both fertility and the incidence of choriocarcinoma increase when there is ABO incompatibility resulting in maternal antigenicity towards the conception. Materno-fetal incompatibility may therefore produce a fetal or tumour advantage via an immune reaction of fetal cells against maternal antigens.

\section{Conclusions}

The human fetus seems capable of both humoral and cellular immune reactions and can produce components of complement and lysozyme from the fourth month of gestation. Tolerance to antigens which are present in early fetal life may not necessarily persist as the fetal immune reactions mature.

Antenatal reactions of the fetus to intrauterine infections are well documented and occasionally the formation of antibodies belonging to one class of immunoglobulins may be accompanied by depressed levels of immunoglobulins of other classes.

In neonatal life antibody production may be modified by maternal antibodies which have crossed the placenta.

In recent years, maternal immunological reactions to fetal antigens have been shown to be often associated with fetal immune reactions to maternal antigens; in some circumstances this type of reaction may favour the survival of the conceptus.

Because of the early maturation of cellular immunity in the human fetus, it is more difficult to achieve acceptance of tissue grafts in newborns with inherited haemopoietic disorders than in experimental animals.

\section{REFERENCES}

Adinolfi, M. (1965). Anti-I antibody in normal human newborn infants. Immunology, 9, 43-52.

Adinolfi, M. (1970). Levels of two components of complement (C'4 and $\mathrm{C}^{\prime} 3$ ) in human fetal and newborn sera. Developmental Medicine and Child Neurology, 12, 306-308.

Adinolfi, M., Gardner, B., Giannelli, F., and McGuire, M. (1967). Studies on human lymphocytes stimulated in vitro with anti- $\gamma$ and anti- $\mu$ antibodies. Experientia, 23, 271-272. 
Adinolfi, M., Gardner, B., and Wood, C. B. S. (1968). Ontogenesis of two components of human complement $\beta 1 \mathrm{E}$ and $\beta 1 \mathrm{C}-1 \mathrm{~A}$ globulins. Nature, 219, 189-191.

Adinolfi, M., Martin, W., and Glynn, A. (1971). Ontogenesis of lysozyme in man and other mammals. In Protides of the Biological Fluids, 18th Colloquium, vol. 18, pp. 91-93, ed. by H. Peeters. Amsterdam, Elzevier.

Adinolfi, M., Mollison, P. L., Polley, M. J., and Rose, J. M. (1966)$\gamma$ A blood group antibodies. Fournal of Experimental Medicine, 123, 951-967.

Adinolfi, M. and Wood, C. B. S. (1969). Ontogenesis of immunoglobulins and components of complement in man. In Immunology and Development, pp. 27-61, ed. by M. Adinolfi. Spastics International Medical Publications in association with W. Heinemann Medical Books, London.

Alford, C. A., Jr. (1965). Studies on antibody in congenital rubella infection. I. Physico chemical and immunologic investigations of rubella neutralizing antibody. American fournal of Diseases in Children, 110, 455-463.

Alford, C. A., Schaefer, J., Blankenship, W. J., Straumfiord, J. V., and Cassady, G. (1967). A correlative immunologic, microbiologic and clinical approach to the diagnosis of acute and chronic infections in newborn infants. New England fournal of Medicine, 277, 437-449.

Bagshawe, K. D., Rawlins, G., Pike, M. C., and Lawler, S. (1971). ABO blood groups in trophoblastic neoplasia. Lancet, 1, 553556.

Brody, J. I., Oski, F. A., and Wallach, E. E. (1968). Neonatal lymphocyte reactivity as an indicator of intrauterine bacterial contact. Lancet, 1, 1396-1398.

Burnet, F. M. (1970). Quoted in Dwyer and MacKay (1970). Lancet, 1, 1199-1202.

Butler, N. R., Benson, P. F., Wilson, B. D. R., Perkins, F. T., Ungar, J., and Beale, A. J. (1962). Poliomyelitis vaccine and triple antigen. Efficacy given separately and together. Lancet, 1, 834-836.

Ceppellini, R., Bonnard, G. D., Coppo, F., Miggiano, V. C., Pospisil, M., Curtoni, E. S., and Pellegrino, M. (1971). Mixed leukocyte cultures and HL-A antigens. I. Reactivity of young fetuses, newborns and mothers at delivery. Transplanation Proceedings, 3, 5870.

Crome, P., Moffat, B., and Adinolfi, M. (1971). HL-A antigens in human foetuses. In Protides of the Biological Fluids, 18th Colloquium, vol. 18, pp. 55-61, ed. by H. Peeters. Elsevier, Amsterdam.

Davies, P. A. (1971). Bacterial infection in the fetus and newborn Archives of Diseases in Childhood, 46, 1-27.

Dwyer, J. M. and MacKay, I. R. (1970). Antigen-binding lymphocytes in human fetal thymus. Lancet, 1, 1199-1202.

Faulkner, W. and Borella, L. (1970). Measurement of IgA levels in human cord serum by a new radioimmunoassay. fournal of Immunology, 105, 786-790.

Fink, C. W., Miller, W. E., Jr., Dorward, B., and LoSpalluto, J. (1962). The formation of macroglobulin antibodies. II. Studies on neonatal infants and older children. Fournal of Clinical Investigation, 41, 1422-1428.

Furth, R. van, Schuit, H. R. E., and Hijmans, W. (1965). The immunological development of the human fetus. Fournal of Experimental Medicine, 122, 1173-1188.

Glynn, A., Martin, W., and Adinolfi, M. (1970). Levels of lysozyme in human foetuses and newborns. Nature, 225, 77-78.

Heremans, J. (1960). Les Globulines Sériques du Système Gamma. Leur Nature et leur Pathologie. Masson, Paris and Arscia, Brussels.

Hess, M. W. (1968). Experimental Thymectomy. Possibilities and Limitations. Springer Verlag, Berlin, Heidelberg, and New York.

Koprowski, H., Norton, T. W., Hummeler, K., Stokes, J., Hunt, A. D., Flack, A., and Jervis, G. A. (1956). Immunization of infants with living attenuated poliomyelitis virus. Fournal of the American Medical Association, 162, 1281-1288.

Levi, M. I., Kravtzov, F. E., Levova, T. M., and Fomenko, G. A. (1969). The ability of maternal antibody to increase the immune response in infants. Immunology, 16, 145-148.

McCracken, G. H. and Shinefield, H. R. (1965). Immunoglobulin concentrations in newborn infants with congenital cytomegalic inclusion disease. Pediatrics, 36, 933-937.
Mårtensson, L. (1966). Genes and immunoglobulins. Vox Sanguinis, 11, 521-545.

Märtensson, L. and Fudenberg, H. H. (1965). Gm genes and $\gamma$ G-globulin synthesis in the human fetus. Fournal of Immuno$\log y, 94,514-520$.

Mellbye, O. J. (1966). Reversible agglutination of trypsinised red cells by a $\gamma \mathrm{M}$ globulin synthesized by the human foetus. Scandinavian fournal of Haematology, 3, 310-324.

Mollison, P. L. (1951). Blood Transfusion in Clinical Medicine. Blackwell Scientific, Oxford.

Moore, M. A. S. and Owen, J. J. T. (1967). Experimental studies on the development of the thymus. Fournal of Experimental Medicine, 126, 715-726.

Perkins, F. T., Yetts, R., and Gaisford, W. (1958). Serological response of infants to poliomyelitis vaccine. British Medical fournal, 2, 68-71.

Perkins, F. L., Yetts, R., and Gaisford, W. (1959). Response of infants to a third dose of poliomyelitis vaccine given 10-12 months after primary immunization. British Medical fournal, 1, 680-682.

Porcile, V. (1904). Untersuchungen über der Herkunft der Plazmazellen in der Leber. Beiträge zur pathologischen Anatomie, 36, 375-381.

Remington, J. S. and Miller, M. J. (1966). 19S and 7S anti-toxoplasma antibodies in the diagnosis of acute congenital and acquired toxoplasmosis. Proceedings of the Society for Experimental Biology and Medicine, 121, 357-363.

Rowe, D. S., Crabbé, P. A., and Turner, M. W. (1968). Immunoglobulin D in serum, body fluids and lymphoid tissues. Clinical and Experimental Immunology, 3, 477-490.

Seller, M. J. (1970). Animal models for bone-marrow transplantation. Fournal of Medical Genetics, 7, 305-309.

Seppälä, M. (1971). ABO blood groups in trophoblastic neoplasia. Lancet, 1, 1020.

Silverstein, A. M. and Lukes, R. J. (1962). Fetal response to antigenic stimulus. I. Plasma-cellular and lymphoid reactions in the human fetus to intrauterine infection. Laboratory Investigation, 11, 918-932.

Silverstein, A. M. and Prendergast, R. A. (1970). Lymphogenesis, immunogenesis and the generation of immunologic diversity. In Developmental Aspects of Antibody Formation and Structure, vol. I, pp. 69-77, ed. by J. Sterzl and I. Riha. Academic Press, New York.

Smith, R. T. (1960). Response to active immunization of human infants during the neonatal period. In Ciba Foundation Symposium on Cellular Aspects of Immunity, pp. 348-368, ed. by G. E. W. Wolstenhome and M. A'Connor. Churchill, London.

Smith, R. T. (1968). Development of fetal and neonatal immunological function. In Biology of Gestation, vol. II, pp. 321-354, ed. by N. S. Assali. Academic Press, New York.

Smith, R. T. and Eitzman, D. V. (1964). The development of the immune response. Characterization of the response of the human infant and adult to immunization with Salmonella vaccines. Pediatrics, 33, 163-183.

Solomon, J. B. (1971). Foetal and neonatal immunology. In Frontiers of Biology, ed. by A. Neuberger and E. L. Tatum. North-Holland, Amsterdam and London.

Soothill, J. F., Hayes, K., and Dudgeon, J. A. (1966). The immunoglobulins in congenital rubella. Lancet, 1, 1385-1388.

Speiser, P. (1963). Über Antikörperbildung von Säuglingen und Kleinkindern gegen mütterliches Gamma-2-Globulin. Wiener medizinische Wochenschrift, 113, 966-971.

Speiser, P. (1966). New aspects of immunogenetic relations between child and mother. I. Children produce antibodies against their mother's antigen. Annales Paediatrici (Basel), 207, 20-35.

Steinberg, A. G. and Wilson, J. A. (1963). Hereditary globulin factors and immune tolerance in man. Science, 140, 303-304.

Sterzl, J. and Silverstein, A. M. (1967). Developmental aspects of immunity. In Advances in Immunology, vol. 6, pp. 337-459, ed. by F. G. Dixon and H. G. Kunkel. Academic Press, New York.

Stiehm, E. R. and Fudenberg, H. H. (1966). Serum levels of immune globulins in health and disease: a survey. Pediatrics, 37, 715-727.

Vierucci, A., Varone, D., and Ingiulla, A. (1964). La sintesi delle immunoglobuline del tipo IgG (7S) nel periodo fetoneonatale studiata mediante l'impiego dei marcatori genetici $\mathrm{Gm}$. Rivista di Clinica Pediatrica, 74, 505-510. 
Vyas, G. N., Levin, A. S., and Fudenberg, H. H. (1970). Intrauterine isoimmunization caused by maternal IgA crossing the placenta. Nature, 225, 257-276.

Wang, A. C., Faulk, W. P., Stuckey, M. A., and Fudenberg, H. H. (1970). Chemical differences of adult, fetal and hypogamma- globulinemic IgG immunoglobulins. Immunochemistry, 7, 703708.

West, C. D., Hong, R., and Holland, N. H. (1962). Immunoglobulin levels from the newborn period to adulthood and in immunoglobulin deficiency states. fournal of Clinical Investigation, 41, 2054-2064. 